MrLls, R. F. N. (1958). J. gen. Microbiol. 19, 473-481.

\title{
The Effect of Infecting the Cells of the De-embryonated Egg with Influenza Virus on their Uptake of Glucose and Amino Acids
}

\author{
By R. F. N. MILLS
}

Biology Division, Research Department, Boots Pure Drug Co. Ltd., Nottingham

SUMMARY : A method was found for infecting all the cells of the de-embryonated hen's egg with influenza B virus (strain Lee). Infected cells took up more glucose from the culture medium than did uninfected cells. Neither infected nor uninfected cells took up any of six amino acids, given singly. A mixture of thirteen amino acids was taken up well, and to the same extent, by infected and uninfected cells. When cysteine, histidine or methionine was omitted from this mixture, the remaining amino acids were taken up better by uninfected cells than by infected cells; when any other amino acid (arginine, glutamine, isoleucine, leucine, lysine, phenylalanine, threonine, tryptophan, tyrosine, valine) was omitted there was no significant difference in uptake by infected and uninfected cells. In this system, ethionine delayed multiplication of influenza virus, but $\beta$-phenylserine did not. These results are consistent with an increased requirement of the infected cell in this system for cysteine, histidine and methionine.

Amino acid analogues, e.g. methoxinine and ethionine (Ackermann, $1951 b$ ) and phenylserine (Dickinson \& Thompson, 1957) have been found to inhibit virus growth in tissue culture in concentrations tolerated by the tissue; their activity was annulled by the corresponding natural amino acids. This suggested that virus-infected cells needed more of certain amino acids than did uninfected cells. In turn, knowledge of increased needs for amino acids by virus-infected cells might act as a guide to other amino acid analogues capable of inhibiting virus growth. The present work reports a search for such increased needs by measuring the uptake of amino acids by normal and virus-infected cells.

For this work it seemed advisable to use a uniform population of cells and a non-cytopathogenic virus. The cells of the de-embryonated hen's egg, which are said to be very uniform (Henle, 1953), and influenza $B$ virus, strain Lee, were chosen. Lee virus has the added advantage that it gives rise to 'incomplete' virus less readily than do other strains of influenza virus (Fazekas de St Groth \& Graham, 1954), so avoiding possible complications from this cause. To make any effect of infection as clear as possible it was necessary to infect all the exposed cells; it also seemed likely that decreasing the concentration of internal metabolites by starvation might make effects of infection on uptake clearer. In view of this, preliminary studies were made to find the effect of starvation on virus production and the conditions necessary for infecting all the cells. A study of the effect of infection on glucose uptake similar to those of Ackermann (1951 a) and Bauer (1953), made as a preliminary to work on amino acid uptake, is also reported here. 


\section{METHODS}

Viruses. Influenza B virus (strain Lee) was propagated in the allantoic sacs of 10-day eggs, harvested after $48 \mathrm{hr}$., and stored at $-60^{\circ}$ as a 1/100 dilution of infected allantoic fluid in Lab-Lemco broth. For experimental use, $0 \cdot 1 \mathrm{ml}$. of a 1/10 dilution of stock virus was inoculated into the allantoic sacs of 9-day eggs; the allantoic fluid was harvested after $42 \mathrm{hr}$. incubation and used immediately.

Influenza A virus (strain PR 8) was used in some experiments on interference. It was propagated, stored and used in the same way as Influenza $B$ virus.

Both strains were estimated by a modification of the method of Salk (1944). Serial twofold dilutions of $\mathbf{0 . 2 5} \mathrm{ml}$. infected fluid were made in normal saline in cups in a Perspex plate; $0.25 \mathrm{ml}$. of a $0.5 \%(\mathrm{v} / \mathrm{v})$ suspension of washed fowl red blood cells was added; the mixture was shaken and allowed to settle for $1 \mathrm{hr}$. The end-point was taken as the last cup showing complete patterning, and the result expressed as the reciprocal of the final dilution of infected fluid.

Cells. The cells of the de-embryonated hen's egg (Bernkopf, 1949) were used. The eggs were 14-15 days old when de-embryonated.

De-embryonation. The method of Finter, Liu, Liebermann \& Henle (1954) was used. Eggs were sealed with bottle-caps waxed in position, or more conveniently with the rubber liners of blood transfusion bottle caps (which stayed in place without waxing). The eggs were rotated at $5 \mathrm{rev} . / \mathrm{hr}$. during the experiments.

Media. After de-embryonation the eggs were washed out with physiological saline. For all other work a balanced salt solution (BSS) containing the salts of the medium of Hanks \& Wallace (1949) was used. The basal medium was supplemented as required with amino acids and with glucose $(0.5 \mathrm{mg} . / \mathrm{ml}$. for work on glucose uptake, $1 \mathrm{mg} . / \mathrm{ml}$. for work on amino acid uptake).

Glucose estimation. The method of Somogyi (1945a) was used, the fluids being deproteinized with barium hydroxide and zinc sulphate (Somogyi, $1945 b)$ and the precipitate removed by centrifugation. The method was accurate to $2 \%$ at a glucose concentration of $0.5 \mathrm{mg} . / \mathrm{ml}$. It was sensitive to $5 \mu$ g. glucose $/ \mathrm{ml}$.

Amino acid estimation. The colorimetric method of Smith \& Agiza (1951) was used. More satisfactory results were obtained by omitting the sodium chloride, and by extracting the coloured material into $5 \mathrm{ml}$. $n$-butanol added from a pipette. The accuracy of the method was $5 \%$ for $10 \mu \mathrm{g}$. $\alpha$-amino- $\mathrm{N} / \mathrm{ml}$.; it was sensitive to $0 \cdot 2 \mu \mathrm{g}$. $\alpha$-amino- $\mathrm{N} / \mathrm{ml}$.

In all estimations the glucose or amino acid in the original medium was used as a standard. For colorimetry a series of concentrations of amino acid in BSS was always prepared to test the linearity of the colour response: this linearity held to at least twice the concentration of amino acid used experimentally.

\section{Plan of experiments}

Apart from some preliminary experiments, described below, and tests of amino acid analogues for ability to decrease virus growth, the following general 
plan was adopted. After the eggs had been de-embryonated and washed twice with saline, 10-15 ml. BSS without glucose was pipetted into each egg and the eggs were then rotated for $24 \mathrm{hr}$. After this preliminary starvation the fluids were decanted from the eggs. The eggs were then rinsed-out with $5 \mathrm{ml}$. BSS (which now, and in the rest of the experiment, contained glucose and was supplemented with amino acids as required), and filled with $10-15 \mathrm{ml}$. of the same fluid. After this, one of two treatments was used. For work on glucose uptake and some early work on amino acid uptake the eggs were rotated 24 $\mathrm{hr}$., then the fluids removed for titration of residual substrate. The eggs were then rinsed-out, refilled with fresh medium, and infected with $0.1 \mathrm{ml}$. undiluted influenza $B$. The eggs were then rotated $24 \mathrm{hr}$., and the fluids removed and saved for haemagglutinin titration. The eggs were rinsed-out and refilled as before, rotated $24 \mathrm{hr}$., then drained and the fluids saved for estimation of haemagglutinin and residual substrate. Uninfected controls were run at the same time and also infected and uninfected eggs for which no amino acids had been added to the BSS + glucose solution. Uptake of glucose on the second and fourth days was measured and the change in uptake for each egg found. The effect of infection was obtained by comparing the changes in uptake for infected and uninfected groups of eggs.

This method resulted in a big leakage of ninhydrin-positive material into the medium towards the end of the experiment. To shorten the experiment, and so decrease this leakage, the eggs in later experiments on amino acid uptake were infected immediately after their preliminary starvation. With this method no allowance could be made for the inherent variation in uptake of different eggs; this decreased the sensitivity of the method.

Assessment of results. During these experiments chorio-allantoic membranes often became detached from the egg shells. This resulted in a big increase in glucose uptake and of leakage of ninhydrin-positive material into the medium. Because of this, all results on fluids from eggs with detached membranes have been excluded.

The significance of the effect of infection on glucose uptake was found by the ' $t$ ' test, using the differences in uptake of glucose between days 2 and 4 for infected and uninfected eggs. For uptake of amino acids an analysis of variance was made, and the significance of the interaction factor for infection and amino acid addition calculated (Snedecor, 1946). As only one degree of freedom was associated with the interaction factor, the square root of the value of ' $F$ ' was taken and a table of ' $t$ ' entered with this.

\section{RESUL'TS}

Effect of starvation on production of influenza $B$ haemagglutinin

Eggs were de-embryonated, washed and starved for $\mathbf{2 4} \mathrm{hr}$. as described above. They were then infected with $0.5 \mathrm{ml}$. undiluted allantoic fluid and rotated for $1 \mathrm{hr}$. The eggs were then drained, rinsed-out and refilled with BSS alone, and some eggs given BSS + glucose $0.5 \mathrm{mg} . / \mathrm{ml}$. They were then rotated a further $24 \mathrm{hr}$. and the haemagglutinin titrated. In agreement with the results of 
Daniels, Eaton \& Perry (1952) it was found that only those eggs given glucose produced detectable haemagglutinin.

\section{Infection of all the cells of the de-embryonated egg}

To make any effects of infection as clear as possible it was desirable to infect all the exposed cells of the chorio-allantoic membrane. To test for this attempts were made to grow influenza $A$ virus in eggs previously infected with influenza $B$ virus. Cells previously infected with influenza $B$ virus do not support the growth of influenza A virus (Henle, 1953); therefore, when eggs after infection with influenza $B$ virus and super-infection with influenza $A$ virus gave detectable influenza A haemagglutinin, this indicated that not all the cells had been infected with influenza $B$ virus. In performing the experiment eggs were de-embryonated, starved $24 \mathrm{hr}$. then rotated $24 \mathrm{hr}$. with $\mathrm{BSS}+$ glucose $(0.5 \mathrm{mg} . / \mathrm{ml}$.). They were then drained, refilled and infected with influenza $\mathbf{B}$ virus. At different times the eggs were drained, refilled and infected with influenza A virus (0.5 ml. undiluted allantoic fluid). After $1 \mathrm{hr}$. the eggs were drained and refilled and excess antiserum (prepared in rabbits) to influenza $B$ virus added. The eggs were rotated $24 \mathrm{hr}$., and the haemagglutinins were checked for specificity against antiserum to influenza A virus. Controls were infected with influenza B virus only (+ normal serum) or with influenza A virus only. The results are shown in Table 1 . The presence of normal serum had no

Table 1. The time of exposure to influenza $B$ necessary to prevent the growth of superinfecting influenza $A$ in the de-embryonated eggs

Antiserum to influenza $B$ was added after the cells had been exposed to the influenza $B$ inoculum for the time shown and then superinfected with influenza $A$ for $1 \mathrm{hr}$. It was sufficient to neutralize all the influenza B liberated from the cells. Antiserum to influenza A neutralized 4 haemagglutination (HA) units influenza $A$ at a dilution of $1 / 320$; antiserum to influenza $B$ neutralized $4 \mathrm{HA}$ units influenza $B$ at a dilution of $1 / 160$. Neither antiserum neutralized the heterologous strain at a dilution of $1 / 40$.

\begin{tabular}{|c|c|c|c|c|c|c|}
\hline \multirow[b]{2}{*}{$\begin{array}{l}\text { Egg } \\
\text { no. }\end{array}$} & \multicolumn{3}{|c|}{ Additions to eggs } & \multirow{2}{*}{$\begin{array}{c}\text { Period of } \\
\text { adsorption } \\
\text { for flu B } \\
\text { virus (hr.) }\end{array}$} & \multirow{2}{*}{$\begin{array}{c}\text { Final } \\
\text { haemagglutinin } \\
\text { titre }\end{array}$} & \multirow{2}{*}{$\begin{array}{c}\text { Haemagglutinin } \\
\text { after exposure } \\
\text { to flu A } \\
\text { antiserum }\end{array}$} \\
\hline & $\begin{array}{l}\text { Flu A } \\
\text { virus }\end{array}$ & $\begin{array}{c}\text { Flu B } \\
\text { virus }\end{array}$ & $\begin{array}{c}\text { Antiserum } \\
\text { to flu B }\end{array}$ & & & \\
\hline \multicolumn{7}{|c|}{ Experiment 1} \\
\hline 1 & + & + & + & 2 & 128 & $<4$ \\
\hline 2 & + & + & + & 2 & 128 & $<4$ \\
\hline $\mathbf{3}$ & + & + & + & 2 & 32 & $<4$ \\
\hline 4 & + & + & + & 4 & 128 & $<4$ \\
\hline 5 & + & + & + & 4 & 16 & $<4$ \\
\hline 6 & + & + & + & 4 & 32 & 4 \\
\hline 7 & - & + & - & 4 & 32 & - \\
\hline 8 & - & + & - & 4 & 32 & - \\
\hline 9 & - & + & - & 4 & 128 & - \\
\hline 10 & + & - & + & - & 128 & - \\
\hline 11 & + & - & + & - & 128 & - \\
\hline \multicolumn{7}{|c|}{ Experiment 2} \\
\hline $\mathbf{1}$ & + & + & + & 24 & $<4$ & - \\
\hline $\mathbf{2}$ & + & + & + & 24 & $<4$ & - \\
\hline 3 & - & + & - & 24 & 16 & - \\
\hline 4 & - & + & - & 24 & 8 & . \\
\hline 5 & + & - & + & . & 16 & . \\
\hline 6 & + & - & + & . & 16 & - \\
\hline
\end{tabular}


effect on the amount of haemagglutinin produced. A $4 \mathrm{hr}$. infection period with $0.5 \mathrm{ml}$. undiluted influenza $B$ virus containing $10^{9.7}$ infectious doses $/ \mathrm{ml}$. did not infect all the cells since influenza $A$ virus subsequently grew. Exposure for $24 \mathrm{hr}$. (in which time several cycles of virus multiplication were possible) to $0.1 \mathrm{ml}$. undiluted influenza $B$ virus was usually sufficient to prevent detectable production of influenza A haemagglutinin; hence a $24 \mathrm{hr}$. infection period was adopted for the work on uptake of glucose and amino acids. In these conditions an inoculum of haemagglutination titre 1024 and infectivity in the allantoic sac of $10^{8} \mathrm{egg}$ infective doses (EID)/0.1 ml. gave rise to fluid in the de-embryonated egg of haemagglutination titre 32 and infectivity $10^{7}$ EID $/ 0 \cdot 1 \mathrm{ml}$.

\section{Effect of infection on the uptake of glucose}

Early experiments showed that there was no detectable production of reducing substances in the de-embryonated egg in absence of glucose. When uptake of glucose by normal and infected eggs was measured it was found that infection increased uptake (Table 2). The effect was quite small but was statistically significant $(0.02<p<0.05$ in the experiment shown) and was obtained in each of four experiments.

Table 2. Increased uptake of glucose in de-embryonated eggs after infection with influenza $B$ virus

Initial glucose concentration was $2 \cdot 4 \mathrm{mg} . / 5 \mathrm{ml}$. Fluids in the eggs were changed daily. For the first day no glucose was present. Eggs were infected after 2 days.

\begin{tabular}{|c|c|c|c|c|c|c|}
\hline \multirow[b]{2}{*}{$\begin{array}{l}\text { Egg } \\
\text { no. }\end{array}$} & \multirow{2}{*}{$\begin{array}{c}\text { Infection } \\
\text { with } \\
\text { flu B } \\
\text { virus }\end{array}$} & \multicolumn{2}{|c|}{$\begin{array}{l}\text { Haemagglutination } \\
\text { at }\end{array}$} & \multicolumn{2}{|c|}{$\begin{array}{c}\text { Glucose }(\mathrm{mg} . / 5 \mathrm{ml} .) \\
\text { recovered at }\end{array}$} & \multirow[b]{2}{*}{$\begin{array}{l}\text { Difference } \\
\text { (2-4 days) }\end{array}$} \\
\hline & & 3 days & 4 days & 2 days & 4 days & \\
\hline 1 & + & 4 & 8 & 1.85 & 1.94 & -0.09 \\
\hline 2 & + & 8 & 16 & $1 \cdot 80$ & 1.76 & +0.04 \\
\hline 3 & + & 8 & 16 & 1.98 & 1.78 & +0.20 \\
\hline 4 & - & . & . & 1.66 & 1.85 & $-0 \cdot 19$ \\
\hline 5 & - & . & . & $1 \cdot 58$ & 2.02 & -0.44 \\
\hline 6 & - & . & . & 1.64 & $1 \cdot 84$ & -0.20 \\
\hline
\end{tabular}

Effect of infection on the uptake of amino acids

Work on the uptake of amino acids was made more difficult by a continuous and variable leakage of ninhydrin-positive material from the cells into the experimental fluid. Deproteinizing followed by boiling for $30 \mathrm{~min}$. in $2 \mathrm{~N}-$ $\mathrm{NaOH}$ decreased the amount of ninhydrin-positive material only by $20 \%$. It seems likely that the remaining $80 \%$ was largely made up of amino acids (amino acids were shown to be present by paper chromatography of the de-salted fluid) but this has not been definitely established. Because of this leakage, eggs given BSS unsupplemented with amino acids were used as controls in all experiments. Amino acid uptake was defined as 'amino acid concentration initially present + average concentration of ninhydrin material finally present in control eggs-average concentration of ninhydrin-positive material finally present in experimental eggs'. 
Uptake of amino acids given singly. No uptake of glycine, serine, phenylalanine, lysine, tryptophan or alanine (initial concentration $10 \mu \mathrm{g}$. $\alpha$-amino$\mathrm{N} / \mathrm{ml}$.) by infected or uninfected eggs was found.

Uptake of mixtures of amino acids. Casein hydrolysate (Allen \& Hanbury 'vitamin free') at an initial concentration of $100 \mu \mathrm{g} . / \mathrm{ml}$. was taken up readily. Uptake ranged from 35 to $100 \%$ in different experiments; it was not affected by infection with influenza $B$ virus. $A$ defined mixture of amino acids was tried next. Eagle $(1955 a, b)$ found that 13 amino acids were required for the growth of several strains of animal cells in tissue culture, so these amino acids were used. For convenience of estimation their concentrations were half those required for optimal growth of cells of the human epidermoid carcinoma HeLa (Eagle, 1955 a). Most of the amino acids were available only as the DL-forms so the quantities of these were doubled to maintain the concentrations of the L-forms at the desired concentrations. (Eagle, $1955 a$, found that the D-amino acids had no effect on cell growth.) Good uptake of this mixture was found but there was no difference in the uptakes of infected and uninfected cells.

Because of the good uptake of the defined mixture of amino acids, the effect of omitting single amino acids from it was tested. When cysteine, histidine, or methionine was omitted the remaining amino acids were taken up better by uninfected than by infected cells (Table 3). For each amino acid the effect was highly significant ( $p<0.001$ for the combined experiments). Omission of any other amino acid had no significant effect on amino acid uptake. For each amino acid omitted (except isoleucine) different experiments gave both bigger and smaller uptakes by infected eggs than by uninfected eggs. When isoleucine was omitted, in three separate experiments, uptake was bigger by uninfected than by infected eggs, but the difference was small.

\section{Action of DL- $\beta$-phenylserine and DL-ethionine on growth of influenza $B$ in de-embryonated eggs}

Ackermann (1951 $b$ ) reported ethionine, and Dickinson \& Thompson (1957) $\beta$-phenylserine, to delay growth of influenza $\mathbf{A}$ in isolated chorio-allantoic membrane and to be antagonized by the analogous natural amino acids (methionine and phenylalanine, respectively). In view of the results obtained here on amino acid uptake it was of interest to test these two compounds for ability to delay growth of influenza $B$ in de-embryonated eggs. DL-ethionine was obtained from Ashe Laboratories Ltd., Leatherhead, Surrey; DL- $\beta$-phenylserine was made in our laboratories.

After $24 \mathrm{hr}$. starvation, de-embryonated eggs were filled with $10 \mathrm{ml}$. BSS + $1 \mathrm{mg}$. glucose $/ \mathrm{ml}$., infected with $0.1 \mathrm{ml}$. undiluted influenza B and rotated for $1 \mathrm{hr}$. The eggs were then drained, rinsed-out and refilled with BSS + glucose + $2 \mathrm{mg} . / \mathrm{ml}$. of the amino acid analogue. The eggs were then rotated and haemagglutinin was titrated at $24 \mathrm{hr}$. intervals. In these conditions DL-ethionine delayed influenza growth markedly (Table 4) but DL- $\beta$-phenylserine did not. The activity of DL-ethionine was annulled by DL-methionine, $1 \mathrm{mg} . / \mathrm{ml}$. 
Table 3. The uptake of a mixture of 13 amino acids by infected and uninfected cells of the de-embryonated egg and of similar mixtures with one amino acid omitted

The complete amino acid mixture contained ( $\mu$ g. $\alpha$-amino-N/ml.): L-arginine, 0.85 ; L-cysteine, 0.17; L-glutamine, 3.5; DL-histidine, 0.35; DD-isoleucine,1.4; DL-leucine, 1.4; DL-lysine, 1.4; DL-methionine, 0.35; DL-phenylalanine, 0.7 ; DL-threonine, 1.4 ; DL-tryptophan, $0.14 ;$ L-tyrosine, 0.7 ; DL-valine, 1.4 .

\begin{tabular}{|c|c|c|c|c|c|c|c|}
\hline \multirow[b]{3}{*}{$\begin{array}{l}\text { Amino acid } \\
\text { omitted }\end{array}$} & & \multicolumn{5}{|c|}{ Ninhydrin-positive material ( $\mu \mathrm{g} . \alpha$-amino-N/ml.) } & \multirow[b]{3}{*}{$\mathbf{P}^{*}$} \\
\hline & & \multicolumn{2}{|c|}{ Average final } & \multicolumn{3}{|c|}{ Average uptake $\dagger$} & \\
\hline & Initial & $\begin{array}{l}\text { Uninfected } \\
\text { eggs }\end{array}$ & $\begin{array}{l}\text { Infected } \\
\text { eggs }\end{array}$ & $\begin{array}{l}\text { Uninfected } \\
\text { eggs (U) }\end{array}$ & $\begin{array}{l}\text { Infected } \\
\text { eggs (I) }\end{array}$ & $\begin{array}{c}\text { Difference } \\
(\mathbf{U}-\mathbf{I})\end{array}$ & \\
\hline None & $\begin{array}{r}0 \\
13 \cdot 3\end{array}$ & $\begin{array}{r}9.0 \\
13.7\end{array}$ & $\left.\begin{array}{l}14 \cdot 5 \\
16 \cdot 2\end{array}\right\}$ & $8 \cdot 6$ & $11 \cdot 6$ & $-3 \cdot 0$ & c. 0.45 \\
\hline None & $\begin{array}{r}0 \\
13 \cdot 3\end{array}$ & $\begin{array}{r}5 \cdot 2 \\
13 \cdot 2\end{array}$ & $\left.\begin{array}{r}6 \cdot 0 \\
17 \cdot 3\end{array}\right\}$ & $5 \cdot 3$ & $\mathbf{2 \cdot 0}$ & $+2 \cdot 0$ & c. $\mathbf{0} \cdot \mathbf{3}$ \\
\hline Cysteine & $\begin{array}{r}0 \\
13 \cdot 1\end{array}$ & $\begin{array}{r}3 \cdot 5 \\
10 \cdot 2\end{array}$ & $\left.\begin{array}{r}7 \cdot 1 \\
17 \cdot 3\end{array}\right\}$ & $6 \cdot 5$ & $\mathbf{3 \cdot 0}$ & $+3 \cdot 5$ & $<0.02$ \\
\hline Cysteine & $\begin{array}{r}0 \\
13 \cdot 1\end{array}$ & $\begin{array}{l}4 \cdot 5 \\
9 \cdot 7\end{array}$ & $\left.\begin{array}{r}7 \cdot 2 \\
16 \cdot 4\end{array}\right\}$ & $7 \cdot 9$ & $3 \cdot 9$ & +4.0 & $<0.02$ \\
\hline Cysteine & $\begin{array}{r}0 \\
13 \cdot 1\end{array}$ & $\begin{array}{r}8 \cdot 9 \\
12 \cdot 6\end{array}$ & $\left.\begin{array}{r}9 \cdot 6 \\
17 \cdot 3\end{array}\right\}$ & $\mathbf{9 \cdot 4}$ & $5 \cdot 4$ & $+4 \cdot 0$ & c. 0.4 \\
\hline Histidine & $\begin{array}{r}0 \\
13 \cdot 0\end{array}$ & $\begin{array}{l}5 \cdot 8 \\
0 \cdot 2\end{array}$ & $\left.\begin{array}{r}7 \cdot 9 \\
16 \cdot 7\end{array}\right\}$ & $9 \cdot 6$ & $4 \cdot 2$ & $+5 \cdot 4$ & $<0.05$ \\
\hline Histidine & $\begin{array}{r}0 \\
13 \cdot 0\end{array}$ & $\begin{array}{r}6 \cdot 1 \\
10 \cdot 1\end{array}$ & $\left.\begin{array}{r}5 \cdot 6 \\
20 \cdot 3\end{array}\right\}$ & $9 \cdot 0$ & $-1 \cdot 7$ & $+10 \cdot 7$ & $<0.01$ \\
\hline Histidine & $\begin{array}{r}0 \\
13 \cdot 0\end{array}$ & $\begin{array}{r}6.0 \\
10 \cdot 0\end{array}$ & $\left.\begin{array}{r}8 \cdot 2 \\
16 \cdot 7\end{array}\right\}$ & $9 \cdot 0$ & $4 \cdot 5$ & +4.5 & c. $\mathbf{0} \cdot \mathbf{2}$ \\
\hline Methionine & $\begin{array}{r}0 \\
13 \cdot 0\end{array}$ & $\begin{array}{r}7 \cdot 2 \\
13 \cdot 7\end{array}$ & $\left.\begin{array}{r}5 \cdot 9 \\
18 \cdot 5\end{array}\right\}$ & $6 \cdot 5$ & 0.4 & $+6 \cdot 1$ & $<0.01$ \\
\hline Methionine & $\begin{array}{r}0 \\
13 \cdot 0\end{array}$ & $\begin{array}{l}5 \cdot 2 \\
9 \cdot 6\end{array}$ & $\left.\begin{array}{r}5 \cdot 9 \\
15 \cdot 0\end{array}\right\}$ & $8 \cdot 6$ & $\mathbf{3 \cdot 9}$ & $+4 \cdot 7$ & c. $0 \cdot 25$ \\
\hline Methionine & $\begin{array}{r}0 \\
13 \cdot 0\end{array}$ & $\begin{array}{r}5 \cdot 4 \\
13 \cdot 4\end{array}$ & $\left.\begin{array}{r}7 \cdot 9 \\
19 \cdot 4\end{array}\right\}$ & $5 \cdot 0$ & $1 \cdot 5$ & $+3 \cdot 5$ & $<0.02$ \\
\hline
\end{tabular}

Table 4. The action of DL-ethionine and DL- $\beta$-phenylserine on growth of influenza $B$ virus in the de-embryonated egg

Experiment 1

\begin{tabular}{cccc} 
Egg & DL-Ethionine & \multicolumn{2}{c}{$\overbrace{20}^{\text {HA }}$} \\
no. & (2 mg./ml. $)$ & $44 \mathrm{hr}$. \\
1 & + & $<4$ & 8 \\
2 & + & $<4$ & 8 \\
3 & + & $<4$ &.$\dagger$ \\
4 & + & $<4$ &. \\
5 & - & 16 &. \\
6 & - & 32 &. \\
7 & - & 16 &.
\end{tabular}

Experiment 2

$\begin{array}{ccc} & \text { DL- } \beta- & \\ \text { Egg } & \begin{array}{c}\text { Phenylserine } \\ \text { no. }\end{array} & \text { HA* at } \\ \text { (2 mg./ml. }) & 24 \text { hr. } \\ 1 & + & 64 \\ 2 & + & 32 \\ 3 & - & 16 \\ 4 & - & 8 \\ 5 & - & 8\end{array}$

* HA = haemagglutination titre. $\uparrow$ Not tested. 


\section{DISCUSSION}

To make any effect of infection on cell metabolism as clear as possible, a uniform population of cells, all of which are infected, should be used. This ideal has only partly been realized: the cells of the de-embryonated egg directly exposed to the experimental fluid are known to be very uniform (Henle, 1953), and all exposed cells were infected, but the underlying cells may have contributed to amino acid and glucose uptake. However, the increased uptake of glucose and increased leakage of ninhydrin-positive material when both sides of the chorio-allantoic membrane are exposed (when it becomes detached from the shell) suggest that this contribution is normally small. Cairns \& Fazekas de St Groth (1957) estimated that there were $3 \times 10^{7}$ allantoic cells lining the chorio-allantoic membrane of the 15-day egg. This number implies that in the present work exposure to 100 egg infectious doses of virus/cell for $4 \mathrm{hr}$. was insufficient to infect every cell. Use of several cycles of virus multiplication to infect every cell made it impossible to relate effects on uptake to specific stages of virus development, but did not make these effects any less real.

Infection of the cells of the de-embryonated egg decreased the uptake of mixtures of amino acids from which cysteine, histidine or methionine had been omitted. This suggested an increased need of the infected cell for these three amino acids. The observed decrease in uptake could not be due to exhaustion of cells producing virus in unphysiological conditions : no difference in uptake was obtained when the complete mixture was used or when any one of the other ten amino acids was omitted, and infection stimulated glucose uptake. The interpretation of the results as an increased need by infected cells for cysteine, histidine and methionine is strengthened by the inhibition of influenza growth in the de-embryonated egg by the methionine analogue ethionine, but not by the phenylalanine analogue $\beta$-phenylserine. The lack of activity of $\beta$-phenylserine in the de-embryonated egg, though consistent with the results on amino acid uptake, is surprising since the de-embryonated egg is of the same tissue as the isolated chorio-allantoic membrane (in which the analogue is a powerful inhibitor of virus multiplication.) The reason for this difference is not known; Mrs M. J. Thompson (personal communication) has shown that it is not due to the virus strain used, the age of the tissue, the preliminary starvation, or the culture medium. Although results obtained in a tissue culture system need not apply to the intact animal, the results reported here suggest that it might be worth while to examine analogues of cysteine, histidine and methionine for ability to inhibit influenza growth.

I wish to thank Dr Loïs Dickinson for advice and criticism throughout this work, Dr M. R. Gurd for advice on the statistical analysis, Mr P. Oxley for a supply of DL- $\beta$-phenylserine, Dr G. Woolfe and Mr C. E. Coulthard for their interest, and Miss M. L. Rose and Miss J. M. Simpson for technical assistance. 


\section{REFERENCES}

Ackermann, W. W. $(1951 a)$. Concerning the relation of the Krebs cycle to virus propagation. J. biol. Chem. 189, 421.

AckermanN, W. W. $(1951 b)$. The role of L-methionine in virus propagation. J. exp. Med. 93, 337.

Bauer, D. J. (1953). Metabolic aspects of virus multiplication. Symp. Soc. gen. Microbiol. 2, 46.

BERNKopf, H. (1949). Cultivation of influenza virus on the chorio-allantoic membrane of the de-embryonated egg. Proc. Soc. exp. Biol., N.Y. 72, 680.

Cairns, H. J. \& Fazekas de St Groth, S. (1957). The number of allantoic cells in the chick embryo. J. Immunol. 78, 191.

Daniels, J. B., Eaton, M. D. \& Perry, M. E. (1952). Effect of glucose on the growth of influenza virus in de-embryonated eggs and tissue cultures. J. Immunol. 69, 321.

Dickinson, L. \& Thompson, M. J. (1957). The antiviral action of threo- $\beta$-phenylserine. Brit. J. Pharmacol. 12, 66.

EAGLe, H. (1955 a). The specific amino acid requirements of a human carcinoma cell (strain HeLa) in tissue culture. J. exp. Med. 102, 37.

EAgLe, H. (1955b). Propagation in a fluid medium of a human epidermoid carcinoma, strain KB. Proc. Soc. exp. Biol., N.Y. 89, 362.

Fazekas de St Groth, S. \& Graham, D. M. (1954). The production of incomplete virus particles among influenza strains: experiments in eggs. Brit. J. exp. Path. 35, 60 .

Finter, N. B., Liu, O. C., Liebermann, M. \& Henie, W. (1954). Studies of hostvirus interaction in the chick embryo-influenza virus system. VIII. An experimental analysis of various de-embryonation techniques. J. exp. Med. 100, 32 .

Hanks, J. H. \& Wallace, R. E. (1949). Relation of oxygen and temperature in the preservation of tissues by refrigeration. Proc. Soc. exp. Biol., N.Y. 71, 196.

Henle, W. (1953). Multiplication of influenza virus in the entodermal cells of the allantois of the chick embryo. Advanc. Virus Res. 1, 142.

SALK, J. E. A. (1944). Simplified procedure for titrating haemagglutinating capacity of influenza virus and corresponding antibody. J. Immunol. 49, 87.

Smrth, A. M. \& AGizA, A. H. (1951). The determination of amino acids colorimetrically by the ninhydrin reaction. Analyst, 76, 623 .

SNEDecor, G. W. (1946). Statistical Methods, 4th ed. Ames: Iowa State College Press. Sомості, M. (1945a). A new reagent for the determination of sugars. J. biol. Chem. 160,61 .

Somogyi, M. (1945b). Determination of blood sugars. J. biol. Chem. 160, 69. 